American University Washington College of Law

Digital Commons @ American University Washington College of

Law

Articles in Law Reviews \& Other Academic Journals

Scholarship \& Research

2019

Manufactured Emergencies

Robert Tsai

Follow this and additional works at: https://digitalcommons.wcl.american.edu/facsch_lawrev

Part of the Constitutional Law Commons, Disaster Law Commons, Health Law and Policy Commons, Immigration Law Commons, Jurisprudence Commons, Military, War, and Peace Commons, President/ Executive Department Commons, and the Rule of Law Commons 
THE YALE LAW JOURNAL FORUM

FEBR UARY 15,2020

\title{
Manufactured Emergencies
}

\author{
Robert L. Tsai
}

A B ST RA CT . Emergencies are presumed to be unusual affairs, but the United States has been in one state of emergency or another for the last forty years. That is a concern. The erosion of democratic norms has led not only to the collapse of the traditional conceptual boundary between ordinary rule and emergency governance, but also to the emergence of an even graver problem: the manufactured crisis. In an age characterized by extreme partisanship, institutional gridlock, and technological manipulation of information, it has become exceedingly easy and far more tempting for a President to invoke extraordinary power by ginning up exigencies. To reduce this threat to political order, we must recalibrate judicial incentives to reward good-faith invocations of limited emergency power, while punishing efforts to solve ordinary public-policy disputes by fabricating or grossly exaggerating problems. This Essay is a start: it recommends the situational loss of deference whenever there is reason to believe public officials are lying about an emergency or have grossly exaggerated the nature, severity, or duration of a real problem. It also urges review of emergency-salient facts. These moves are more important, not less, when the government invokes national security. And while it would entail a change in current practice, it would actually represent a return to an older effort on the part of judges to insist upon truth and empiricism. The approach would be helpful, for instance, in legal challenges to Trump's "Muslim ban" and his efforts to unilaterally build a border wall and rewrite immigration policy.

\section{INTRODUCTION}

Once upon a time, emergencies were thought to be extraordinary events. It is not that Presidents did not take the initiative to declare emergencies; they always have, and they always will. But there was a time when a President behaved as if emergencies were temporary, let them expire after a limited time, invoked emergency power in good faith, and acted expecting to be accountable to Congress as well as the American people. Judicial intervention did not happen regularly, but when it did, judges tried to enforce the sense that regular order was expected. For instance, when the Supreme Court ruled that military commissions could not be used when regular courts were capable of fulfilling the 
demands of justice, it insisted, "No doctrine involving more pernicious consequences was ever invented by the wit of man than that any of its provisions can be suspended during any of the great exigencies of government.." Likewise, the Court rebuffed President Truman's effort to seize steel mills during the Korean War by insisting that he had bypassed laws laid out to deal with such situations and by casting doubt on his troubling theory of inherent presidential power. ${ }^{2}$

Then norms began to break down. Or, perhaps, long-eroding norms became more visible. Congress ceded the ability to declare emergencies, mostly by cordoning off areas where Presidents had historically been first movers, such as committing troops abroad. The War Powers Act of 1973 and National Emergencies Act (NEA) of 1976 exemplify this approach. ${ }^{3}$ Ostensibly, these laws represented legislative efforts to reclaim power from the President, but in reality Congress all but gave up the ability to demand a deliberative role before the President acted on many important matters. In exchange, Presidents had to consult with Congress if authority predicated on a crisis needed to be extended. But Congress rarely acted later to stop a President. It was often less politically palatable to try to unwind emergency action after it commenced. Telling is the fact that Congress has never once invoked its power under the NEA to reverse a President's declaration of a national emergency. On top of that, Congress carved out more and more areas for potential emergency governance. By one count, over 136 different statutes currently authorize a President to assert an emergency. ${ }^{4}$

Once Presidents acquired a taste for emergency governance, it became an increasingly preferred way of doing business. It has offered an escape from the drudgery of divided government and the hyper-partisanship that has made Congress an unreliable partner. In practice, a crisis relieves a President from any formal ex ante obligation to build political support for his initiatives. It also helps avoid legislators' tendency to share the credit for dealing with serious problems but dodge blame for hasty judgments. Unburdened by the need for public

1. Ex parte Milligan, 71 U.S. (4 Wall) 2, 120-21 (1866) ("The Constitution of the United States is a law for rulers and people, equally in war and in peace, and covers with the shield of its protection all classes of men, at all times and under all circumstances.").

2. Youngstown Sheet \& Tube Co. v. Sawyer, 343 U.S. 579 (1952).

3. To be sure, the modern trend to legislatively delegate emergency power started during Franklin D. Roosevelt's tenure, to empower the administration to deal with a cratering national economy. See generally Bruce AcKerman, Before the NeXt Attack: Preserving Civil LibERTIES IN AN AGE OF TERRORISM (2006); STEVEN F. GRIFFIN, LONG WARS AND THE CONSTITUtion (2013); Harold Hongu Koh, The National Security Constitution: Sharing Power After the Iran-Contra AfFair (1990).

4. A Guide to Emergency Powers and Their Use, Brennan CTR. FOR Just. (Sept. 4, 2019), https://www.brennancenter.org/analysis/emergency-powers [https://perma.cc/4RM8 -XCWZ]. 
deliberation beforehand, Presidents have sometimes ignored any obligation to consult with key legislators by asserting the need for secrecy and dispatch. ${ }^{5}$

Far from reining in a President, marking off areas suitable for emergency governance has normalized adventurism in those areas and limited accountability. In fact, this past summer, the Trump Administration claimed a continuing national emergency "with respect to transnational criminal organizations," pursuant to the NEA. ${ }^{6}$ The document made conclusory assertions about how the "activities of significant transnational criminal organizations have reached such scope and gravity that they threaten the stability of international political and economic systems," but gave no factual examples. ${ }^{7}$ Few even noticed, much less marked, the occasion. As of February 2019, there were thirty-one active "emergencies" and, as one observer explained, America has been in "a constant state of emergency since 1979."

We have now crossed into an even more perilous time. A new problem rears its head: the manufactured emergency. The manufactured emergency is a public-policy problem whose nature or scope is fabricated or exaggerated beyond reasonable parameters. It is not that Presidents could not make up a crisis out of whole cloth in the past; rather, the difficulty today is that, for many political and technological reasons, the temptation to lie on a grand scale, with potentially disastrous consequences, is historically unprecedented. We are more susceptible to fake crises than ever before. Lies spread quickly and durably through social media, the real-world consequences of acting upon lies and exaggerations have multiplied, and those who gin up an emergency are more able to get away with it. As Russell Muirhead and Nancy Rosenblum have explained, new conspiracist thinking attacks essential democratic norms such as respect for political difference and the epistemological value of truth, as well as "knowledge-producing

5. The Iran-Contra affair arose after President Reagan signed a secret executive order authorizing the CIA to arm the Contra rebels in Nicaragua, in violation of the Boland Amendment. Even when an executive initiative is not illegal, Presidents have withheld information from Congress about planned tactical strikes or other military maneuvers out of fear that knowledge will be leaked to the press. See generally $\mathrm{KoH}$, supra note 3 .

6. Continuation of the National Emergency with Respect to Transnational Criminal Organizations, 84 Fed. Reg. 35,513 (July 23, 2019), https://www.govinfo.gov/content/pkg/FR-2019 -07-23/pdf/2019-15794.pdf [https://perma.cc/4CD7-AUV8]. The Trump Administration has also declared a national emergency to block the property of the Venezuelan government.

7. $\quad I d$.

8. Olivia B. Waxman, Trump Just Declared an Emergency at the Border. The U.S. Has Been in a Constant State of Emergency Since 1979, TIME (Feb. 15, 2019), https://time.com/5496270 /presidents-history-national-emergency [https://perma.cc/8WGV-NoR4]. 
institutions."9 In turn, the political mobilization of untruths and the degradation of democratic norms have made it harder for voters not just to tell the truth from lies, but also to sift significant false statements from ordinary lies.

A manufactured crisis is not when a public official or policy analyst makes a good-faith call about the severity of a problem and turns out to be wrong. Those are excusable mistakes of judgment, grounded in a shared sense of reality and legal norms. Instead, the problem of the fake emergency entails a rejection of the legitimate role that other institutions play within our system of government and the broader culture of respect and accountability-evidenced by a willingness to lie about the motives that led to government action, the ends to which power is dispensed, and ultimately a disdain for the human beings whose lives or property are affected.

Presidents today realize that open-ended grants of authority, coupled with judicial acquiescence, mean their assertions of emergency power nearly always prevail. Given an eye-popping win-loss record under legal frameworks developed for a different time, ${ }^{10}$ a President's temptation when challenged on a wildly implausible emergency is not to back down, but to lie about its nature or scope. All that is required is someone brazen enough to do it.

A populist who lacks civic virtue or exhibits autocratic tendencies creates infinitely more problems for democratic governance. He might direct others to lie about or hide inconvenient information that experts need to do their jobs or that ordinary citizens are entitled to see. His behavior also corrupts other institutions, such as courts, by exploiting rules devised for the benefit of public officials acting in good faith and by expecting that judges fall in line like loyalists rather than exercise independent judgment and due care. On top of that, a conspiracist President, ${ }^{11}$ one who has risen to power in part by harnessing the power of untruths and shadowy claims about one or another cabal, can use the institutions of

9. Russell Muirhead \& Nancy L. Rosenblum, a lot of People are Saying: The New ConSPIRACISM AND THE ASSAULT ON DEMOCRACY 5 (2019); see also ANNE MERLEN, REPUBLIC OF LIES: AMERICAN CONSPIRACY THEORISTS AND THEIR SURPRISING RISE TO POWER 15-16 (2019) (canvassing the history of conspiracism in America, prevalent among populations experiencing "threat and insecurity," which "tend to flourish especially at times of rapid social change").

10. See Fred Barbash \& Deanna Paul, The Real Reason the Trump Administration is Constantly Losing in Court, WASH. POST (Mar. 19, 2019, 12:05 PM EDT), https://www.washingtonpost.com /world/national-security/the-real-reason-president-trump-is-constantly-losing-in-court /2019/o3/19/f5ffbo56-33a8-11e9-af5b-b51b7ff322e9_story.html] [https://perma.cc/9CDR $-\mathrm{N} 7 \mathrm{VF}]$.

11. According to Muirhead and Rosenblum, a "presidential conspiracism" delegitimates existing institutions, distorts their intended operation, and "degrades them in the service of conspiracist claims." MUIRHEAD \& RosenBLUM, supra note 9 , at 71. 
democratic government to pursue objectives that undermine constitutional arrangements or deeply-held political values such as equality or pluralism.

No better evidence of the precipice upon which we find ourselves is the current President's declaration of a national emergency in order to shift monies legislatively allocated for the armed forces to pay for building a giant wall along the Southern border. ${ }^{12} \mathrm{He}$ has repeatedly asked Congress to fund this initiative, and Congress, whose primary constitutional powers include appropriating monies and providing for the common defense, ${ }^{13}$ has persistently refused to pay for it. "We have an invasion of drugs and criminals coming into our country," President Trump declared at a press conference when announcing his unilateral action, mere hours after Congress had enacted a spending measure that excluded funding for his proposed wall. ${ }^{14}$ By invoking the NEA, he sought to invert the ordinary budget process. Legislators would have to muster a veto-proof majority to reverse his emergency-based funding initiative.

President Trump's own experts have said that a border wall is highly unlikely to put a dent in the very problems he claims to be addressing-large numbers of migrants and refugees heading for the United States, the scourge of human trafficking, the perennial law-enforcement concern with drug smuggling. ${ }^{15}$ But no matter: he long ago promised a big, beautiful wall to his supporters, and one way or another, he wants to see it built. Manufacturing an emergency has become the means to invert the regular legislative process and frustrate the preferences of a majority of voters. ${ }^{16}$ An inability to stop him will not only confirm his

12. Proclamation No. 9844, 84 Fed. Reg. 4949 (Feb. 15, 2019). President Trump has also declared an emergency in order to impose "national security" tariffs on China under the Trade Expansion Act. Proclamation No. 9705, 83 Fed. Reg. 11,625 (Mar. 8, 2018). And he has also claimed national security reasons to alter rules governing the handling of asylum claims initiated by migrants from countries to the South. Proclamation No. 9880, 84 Fed. Reg. 21,229 (May 8, 2019).

13. See U.S. CoNST. art. I, $\$ 8$.

14. Peter Baker, Trump Declares a National Emergency, and Provokes a Constitutional Clash, N.Y. Times (Feb. 15, 2019), https://www.nytimes.com/2019/o2/15/us/politics/national -emergency-trump.html [https://perma.cc/U5NN-5KWG].

15. See, e.g., U.S. Dep't of Justice, Drug Enf't Admin., 2018 National Drug Threat AssessMENT 19 ("A small percentage of all heroin seized by CBP along the land border was between Ports of Entry."); Eric Schmitt et al., A Border Wall to Stop Terrorists? Experts Say That Makes Little Sense, N.Y. TIMES (Jan. 8, 2019), https://www.nytimes.com/2019/o1/o8/us /politics/trump-border-wall-terrorists.html [https://perma.cc/JY4J-BYTZ] ("Despite the administration's focus on security threats at the border, a White House strategy document sent to Congress last month outlining steps needed to monitor and intercept terrorists included no reference to the need for construction of barriers, fences or walls.").

16. Jim Norman, Solid Majority Still Opposes New Construction on Border Wall, GALLup (Feb. 4, 2019), https://news.gallup.com/poll/246455/solid-majority-opposes-new-construction- 
frequent boast that he alone can do what is necessary to save the republic - it will merely embolden other, similarly unjustified emergency declarations in the future. ${ }^{17}$

These concerns go well beyond a particular President. In an environment of already degrading political norms, a legal order's tolerance of fake crises breeds what Robert Jay Lifton dubs "a malignant normality" 18 - easing the way for successors and their allies to get away with even more significant breaches of constitutional order and norms that are essential to wise governance.

Part I of this Essay briefly revisits older approaches to emergencies, emphasizing the importance of empirical testing before courts validate emergency authority. It also argues that in a period of democratic decline, judicial passivity can be lethal for the constitutional order. A course correction in terms of institutional orientation is necessary to go along with any changes to doctrine.

We need not return to legal formalism. Part II recommends two modest adjustments that judges can make to discourage the assertion of unilateral power based on fake crises: (1) moving toward a collapsible standard of deference; and (2) engaging in minimal review of emergency-salient facts.

\section{A VERY SHORT HISTORY OF JUDICIAL DEFERENCE TO EMERGENCIES}

We were not always so poised to tolerate manufactured emergencies. In $E x$ parte Milligan, the Supreme Court emphasized that an exigency had to be real. Even in the midst of the Civil War, a crisis that was assuredly not fabricated, judges worried about "pretext" for martial law, which "leads directly to anarchy and despotism." ${ }^{19}$ The concern was that, through an undisciplined assertion of emergency, the conflict would widen in a way that obliterated all semblance of law and order, destroying institutions and civil liberties along the way. "Martial law cannot arise from a threatened invasion," Justice Davis declared. "The

border-wall.aspx [https://perma.cc/M3PA-DPEQ] ("Sixty percent of Americans opposed major new construction of walls along the U.S.-Mexico border - the goal behind President Donald Trump's budget showdown with Democratic leaders ....").

17. "I alone can fix it," Trump famously declared at the 2016 Republican National Convention. Yoni Appelbaum, "I Alone Can Fix It," ATLANTIC (July 21, 2016), https://www.theatlantic.com /politics/archive/2016/o7/trump-rnc-speech-alone-fix-it/492557] [https://perma.cc/QP5K $-6 \mathrm{FST}]$.

18. Robert Jay Lifton, The Climate Swerve: Reflections on Mind, Hope, and Survival 6792 (2017).

19. Ex parte Milligan, 71 U.S. (4 Wall) 2, 121, 127 (1866).

20. Id. at 127 (emphasis removed). 
necessity must be actual and present; the invasion real, such as effectually closes the courts and deposes the civil administration." ${ }^{1}$

Likewise, when Chief Justice Taney declared President Lincoln's unilateral suspension of habeas corpus during the Civil War unconstitutional, he pointed not only to the Constitution's delegation of this power to Congress, but also to the fact that under the circumstances, "[t]here was no danger of any obstruction or resistance to the action of the civil authorities, and therefore no reason whatever for the interposition of the military."22 In other words, the executive branch had not articulated a true exigency sufficient to upend regular constitutional operations. Justice Taney warned that "if the authority which the constitution has confided to the judiciary department and judicial officers, may thus, upon any pretext or under any circumstances, be usurped by the military power, at its discretion, the people of the United States are no longer living under a government of laws." ${ }^{23}$

And, while the framework for analyzing President Truman's seizure of steel mills was largely formalistic in nature, that decision, too, contained many warnings that unconstrained or exaggerated claims of crisis simply would not do. ${ }^{24}$ There is a longer and more complicated history here, ${ }^{25}$ but the key is that the

21. Id. Accord United States v. Russell, 8 o U.S. (13 Wall) 623, 628 (1871) ("Where such an extraordinary and unforeseen emergency occurs in the public service in time of war no doubt is entertained that the power of the government is ample to supply for the moment the public wants in that way to the extent of the immediate public exigency, but the public danger must be immediate, imminent, and impending, and the emergency in the public service must be extreme and imperative, and such as will not admit of delay or a resort to any other source of supply, and the circumstances must be such as imperatively require the exercise of that extreme power in respect to the particular property so impressed, appropriated, or destroyed. Exigencies of the kind do arise in time of war or impending public danger, but it is the emergency, as was said by a great magistrate, that gives the right, and it is clear that the emergency must be shown to exist before the taking can be justified.").

22. Ex parte Merryman, 17 F. Cas. 144, 152 (D. Md. 1861).

23. Id.

24. Youngstown Sheet \& Tube Co. v. Sawyer, 343 U.S. 579, 593 (1952) (Frankfurter, J., concurring) ("Our scheme of society is more dependent than any other form of government on knowledge and wisdom and self-discipline ...."); $i d$. at 650 (Jackson, J., concurring) ("[The Framers] knew what emergencies were, knew the pressures they engender for authoritative action, knew, too, how they afford a ready pretext for usurpation. We may also suspect that they suspected that emergency powers would tend to kindle emergencies.").

25. One of the most infamous misrepresentations came during World War II, when Franklin Roosevelt's administration greatly exaggerated the national security threat posed by people of Japanese ancestry in the United States. Even when confronted with intelligence that undermined the government's claim that Japanese Americans were helping Japan to invade the West Coast, lawyers failed to correct the record, and the U.S. Supreme Court relied upon these false facts when it upheld the evacuation and internment policies in Korematsu v. United States. 323 
nature, scope, and duration of an effort to exercise emergency power was to be limited strictly by a real exigency.

How did we get to a place where such limits have become blurred and watered down? First, coming to power now is the generation that grew up with robust visions of presidential leadership dancing in their heads. For them, Watergate is a distant memory. Many have come to reflexively trust a President and to believe that second-guessing executive action is tantamount to imperiling this country's security. Some acolytes of this view, for instance those associated with the Federalist Society or the Heritage Foundation, have prepared for a long time to implement a vision of the "unitary executive": a President mostly unconstrained in his capacities save having to stand for reelection. ${ }^{26}$ We had a glimpse of this vision of the presidency from the architects of post-9/11 governance. But this is the moment that many legal conservatives have been waiting for.

Second, this long-term ambition is being realized at precisely the moment where other forms of democratic accountability have weakened-dangerously so. As Tom Ginsburg and Aziz Huq have pointed out, problems associated with "charismatic populism" and "partisan degradation" have intensified in the United States. ${ }^{27}$ These developments have put stress on democratic institutions and the notion of a stable rule of law. And elections are no guarantee of respect for tradition, institutions, or liberties. Political parties, too, no longer necessarily constrain a President's invocation of emergency power. To the contrary, other forces, like popular movements that can capture a party's leadership and

U.S. 214 (1944). See Korematsu v. United States, 584 F. Supp. 1406, 1420 (N.D. Cal. 1984) (granting writ of coram nobis to correct the record because "the government deliberately omitted relevant information and provided misleading information in papers before the court," thereby "seriously impair[ing]" the judicial process).

26. See, e.g., Eliana Johnson, The Real Reason Bill Barr is Defending Trump, Politico (May 1, 2019, 5:02 AM EDT), https:/www.politico.com/story/2019/05/01/william-barr-donald-trump -mueller-report-1295273 [https://perma.cc/KK4Z-Y4UM]; Robert L. Tsai, Obstruction of Justice? The Damage Runs Deeper Than That, Bos. Globe (Apr. 19, 2019, 3:57 PM), https://www.bostonglobe.com/ideas/2019/04/19/obstruction-justice-the-damage-runs -much-deeper-than-that/sdY ${ }_{55}$ RoEKti4a1JMNIc8OK/story.html [https://perma.cc/4XAF -GYPH]. See generally StEVEn M. TELES, THE Rise of THE CONSERVATIVE LEGAL MOVEMENT: THE BATtle For Control of THE LAW (2010) (charting the Federalist Society's ascendance through social-network theory and explicating its promotion of the unitary executive).

27. Tom Ginsburg \& Aziz Z. HuQ, How to SAVE a Constitutional Democracy (2018); see also SteVen LeVtTSKY \& Daniel Ziblatt, How Democracies Die (2018); YASCHA MounK, The People vs. Democracy: Why Our Freedom Is in Danger \& How to Save It (2018). To be sure, the rise of authoritarian forms of governance is not unique to the United States. Countries like Venezuela, Turkey, Hungary, Peru, and Poland have experienced similar democratic backsliding, while others like Great Britain and Germany have also had trouble weathering right-wing popular movements. LEVITSKY \& ZIBLATT, supra note 27, at 5 . 
apparatus, may drive the impetus toward emergency governance in ways that overpower experienced, norms-respecting members of a President's own party. As a result, party elders who seem out of step may leave the party or resign from office rather than stay and fight. ${ }^{28}$

Third, in Donald Trump we have a President willing to cast aside remaining democratic norms. He not only believes in the muscular use of his constitutional powers, he also expects there to be few, if any, legal limits to his hopes and desires. He demands aides and lawyers who are ready to fulfill his wishes rather than give him sound, though perhaps disappointing, advice. For the typical populist leader, it might seem like a good idea to have people and institutions bend to your will more easily; but for an erratic figure or one pushing an extreme agenda, it means that democratic guardrails no longer seem secure.

Beyond the policies that severely test the nation's commitment to religious equality and against national-origin discrimination are the symbolic actions that signify a hard-edged disdain for constitutional limits. President Trump has pardoned a sheriff who notoriously violated the rights of undocumented migrants and refused to obey court orders. ${ }^{29}$ He also pardoned a soldier who killed a naked, blindfolded Iraqi during interrogation. ${ }^{30}$ His willingness to personally profit from his time in office, without revealing his financial entanglements, makes mincemeat of the Constitution's anti-corruption requirements for office holders. ${ }^{31}$ More recently, the President's apparent plan to use foreign aid to extort another country, Ukraine, into providing fodder to use against his political rivals

28. In both 2018 and 2019, more Republicans than Democrats have decided to retire. Russell Berman, The 2020 Congressional-Retirement Tracker, ATLANTIC (Oct. 28, 2019, 10:08 AM ET), https://www.theatlantic.com/politics/archive/2019/11/retirement-congress-2020-hurd -alexander/596965 [https://perma.cc/BJ5U-HPWX] ("17 GOP House members and four senators are forgoing reelection ... while just six Democrats in the House and one in the Senate are retiring outright.").

29. Robert L. Tsai, The Troubling Sheriffs' Movement That Joe Arpaio Supports, Politico (Sept, 1, 2017), https://www.politico.com/magazine/story/2017/o9/o1/joe-arpaio-pardon-sheriffs -movement-215566 [https://perma.cc/G2DV-685Z].

30. Reis Thebault, Trump Pardons Former Solider Who Was Convicted of Murdering an Iraqi Prisoner, WASH. POST (May 6, 2019, 10:40 PM EDT), https://www.washingtonpost.com/politics /trump-pardons-the-former-soldier-who-was-convicted-of-murdering-an-iraqi-prisoner /2019/05/06/158765f8-705e-11e9-9fo6-5fc2ee80027a_story.html [https://perma.cc/D47G $-\mathrm{F}_{5} \mathrm{VW}$.

31. Karen Yourish \& Larry Buchanan, Trump Still Makes Money From His Properties. Is This Constitutional?, N.Y. TIMES (July 10, 2019), https://www.nytimes.com/interactive/2018/12/17/us/politics/trump-emoluments-money.html [https://perma.cc/G56AC8XT]. 
betrays a contemptuous view of the law and a lack of concern for the integrity of elections. $^{32}$

Fourth, judges have themselves contributed to the rise of fabricated exigencies by not merely approving aggressive assertions of emergency power, but also tolerating outright lies and thinly veiled rationales devised by lawyers after the fact. ${ }^{33}$ Judicial passivity can be easily exploited by the craven and the mendacious alike. Judges' handling of more routine national security matters, where experts are expected to act with professionalism and good faith, has left them unprepared for fabricated crises. This expectation of regularity runs the risk of relegating judges to the role of mere observers in democracy's decline.

Where the Supreme Court once demanded that an emergency be real, today it will rarely, if ever, scrutinize a President's motives or the evidence underlying a crisis claim. That is especially true when there might be mixed motives: some plausible and some blatantly unconstitutional. Consider the Muslim travel ban, one of many examples from the national security context. Candidate Donald Trump told the world he would try to stop Muslim people from coming to the United States if he were elected, and one of his very first acts as President was to sign an executive order seeking to do just that. In Trump v. Hawaii, ${ }^{34}$ a 5-4 majority of Justices approved a policy that suspended the Syrian refugee program and barred travel from six Muslim-majority countries. The Administration justified this as a national security exception to immigration law, which bans discrimination based on national origin. ${ }^{35}$ Not only did five Justices ignore plentiful statements demonstrating anti-Muslim bias, they took the further step of insulating some of those comments (it is not clear which) by declaring them protected by the First Amendment. ${ }^{36}$

This last point is especially troubling, as it suggests a desire on the part of some jurists to reach for substantive constitutional rights to keep a crisis from close scrutiny. They also refused to sort carefully through the evidence of antiMuslim bias, which included shifting rationales and strategies, or to offer any guidance as to when subsequent changes to policy can be said to cleanse it of bias. ${ }^{37}$ The judicial disregard for truth and clarity exemplified in that decision

32. Sharon LaFraniere, Andrew E. Kramer \& Danny Hakim, Trump, Ukraine and Impeachment: The Inside Story of How We Got Here, N.Y. TIMES (Nov. 11, 2019), https://www.nytimes.com/2019/11/11/us/ukraine-trump.html [https://perma.cc/BRH2-UUNU].

33. See discussion infra Section II.A.

34. 138 S. Ct. 2392 (2018).

35. Id. at 2409 .

36. Id. at 2417-18.

37. Id. 
will make it harder to prove unconstitutional bias in the future - much less stem the damage from a rising ethnonationalist sentiment. ${ }^{38}$

Many judges will be tempted to employ standards of deference and reviewability to avoid having to pronounce that exceptional power is unjustified. That is what the majority did in Trump v. Hawaii. They brushed aside any effort to limit the emergency-based rationales to situations where Congress would have a hard time reacting quickly. ${ }^{39}$ Instead of finding bias, the majority accepted at face value the Administration's argument that each of the countries was singled out for "a bona fide national security" reason (such as, that it was hard to get reliable security information from the country) rather than its demographics. ${ }^{40}$ There was no real analysis of why some countries like Saudi Arabia, which have clearly been linked to sponsoring terrorism, ${ }^{41}$ were not on the list and why others, like North Korea and Venezuela, were added at the last minute as a fig leaf. The Administration defended the ban on grounds of exigency and claimed it was a temporary measure that would be periodically reevaluated. But there is no indication that the Administration will lift or further modify the ban on its own. In the meantime, the evidence is adding up that the ban as enforced is, for all practical purposes, an anti-Muslim policy. ${ }^{42}$

More recently, in a 5-4 vote, the Court lifted a stay in one of the lawsuits challenging the President's shifting of $\$ 2.5$ billion from the Pentagon's budget to

38. Contrast this posture with that of the Supreme Court in the 1940 s, when a number of Justices, such as Robert Jackson, believed it to be imperative for judges to play an active role in embracing the lessons of totalitarianism and taking steps to ensure the survival of democracy in America. See, e.g., Beauharnais v. Illinois, 343 U.S. 250 (1952); W. Va. State Bd. of Educ. v. Barnette, 319 U.S. 624 (1943).

39. Trump v. Hawaii, 138 S. Ct. at 2412.

40. This aspect of the decision replayed the major errors of Korematsu $v$. United States, 323 U.S. 214 (1944), an ironic development since Chief Justice Roberts used the occasion to overrule that decision. See generally Robert L. TSAI, PRACTICAL EQUality: Forging JUSTICE IN A DIVIDED NATION (2019); Robert L. Tsai, The Hidden Costs of Dissent, 35 CONST. COMMENT. 489 (2019).

41. Brahma Chellaney, The Global War on Terrorism Has Failed. Here's How to Win, ForeIGN POL'Y (May 11, 2019, 2:42 PM), https://foreignpolicy.com/2019/05/11/the-global-war-on -terrorism-has-failed-heres-how-to-win [https://perma.cc/A6UT-ABDN]; Rob Hastings, Saudi Arabia is "Biggest Funder of Terrorists," INDEP. (Dec. 6, 2010, 1:00), https://www .independent.co.uk/news/world/middle-east/saudi-arabia-is-biggest-funder-of-terrorists -2152327.html [https://perma.cc/454C-VYV8].

42. See Vahid Niayesh, Trump's Travel Ban Really Was a Muslim Ban, Data Suggests, WASH. Post (Sept. 26, 2019), https://www.washingtonpost.com/politics/2019/o9/26/trumps-muslim -ban-really-was-muslim-ban-thats-what-data-suggest [https://perma.cc/R $7 \mathrm{~K}_{7}-59 \mathrm{UC}$; Robert L. Tsai, Trump's Travel Ban Faces Fresh Legal Jeopardy, POLITICO (Mar. 27, 2019), https://www.politico.com/magazine/story/2019/03/27/trump-travel-ban-lawsuit-supreme -court-unconstitutional-226103 [https://perma.cc/G8ND-8E5Q]. 
begin construction of a border wall. The terse, unsigned order said that "the Government has made a sufficient showing at this stage that the plaintiffs have no cause of action to obtain review." ${ }^{43}$ Most observers believe that the Justices have doubts about the plaintiffs' standing to bring the case. But justiciability doctrines are not neutral, long-standing rules that simply measure whether litigants have a serious stake in a controversy. Rather, they are highly malleable rules of relatively recent vintage that raise the costs of litigation and disempower judges from participating in the project of democratic renewal. ${ }^{44}$ If jurists are willing to invoke such rules when a President has declared a national emergency, they could very well be giving a pass to a fake crisis and contributing to democratic backsliding. ${ }^{45}$

\section{A PROPOSED COURSE CORRECTION}

What is to be done to begin shoring up our legal infrastructure to minimize the number of manufactured crises? The basic principle that emergencies must be real, serious, and verifiable will have to be recovered from the byzantine set of modern doctrines that let executive-branch officials get away with unilateral actions. Truth, knowledge, wisdom, and accountability must be backfilled into the system of checks and balances.

The causes of our current situation run deep, and it will take more than a few doctrinal fixes to arrest patterns of development. But our situation is not hopeless. And we have to start somewhere. There are several legislative possibilities, including scaling back the number of existing laws that confer emergency power on the President or updating them to better constrain leaders hellbent on adventurism. Congress has tried to reclaim power over emergencies before - for inspiration, we need look no further than the original efforts to enact the NEA and the War Powers Act. Doing so again would reduce the opportunities for fake

43. Trump v. Sierra Club, No. 19A60, 2019 WL 3369425, at ${ }^{\star} 1$ (July 26, 2019). Justice Breyer wrote separately to indicate that he would have allowed the government to take bids and sign contracts for the construction of the wall, but not begin construction. See id. at *2 (Breyer, J., concurring in part and dissenting in part from the grant of stay).

44. See, e.g., Patti A. Meeks, Justice Scalia and the Demise of Environmental Law Standing, 8 J. LAND USE \& ENVTL. L. 343, 364 (1993); William A. Fletcher, The Structure of Standing, 98 YALE. L.J. 221, 221-23 (1988); Mark V. Tushnet, The New Law of Standing: A Plea for Abandonment, 62 CORNELL L. ReV. 663, 664 (1977).

45. Perhaps the most dramatic recent example of the Supreme Court leaving the field of action is its decision in Rucho v. Common Cause, 139 S. Ct. 2484 (2019), that partisan gerrymandering raises a non-justiciable "political question." That decision effectively sidelined the entire federal judiciary on a problem that continues to plague America's democracy, one that ordinary politics alone is unlikely to solve anytime soon. 
emergencies and send a signal to courts to play a more active role in policing legislative grants of authority.

As for the problem of judicial complicity, this Essay proposes two changes to help deter manufactured crises: (1) a collapsible approach to judicial deference and (2) a duty to probe emergency-relevant facts.

\section{A. A Collapsible Approach to Judicial Deference}

The first proposal tackles the problem of mechanical rules of deference, with an eye toward recalibrating incentives to discourage lying about emergencies. Modern constitutional analysis has become a set of clunky standards of review that often obscures what is really going on and gives insufficient protection to both government powers and individual liberties. If we cut to the chase, there are three reasons traditionally given for affording government officials some degree of deference: (1) preserving separation of powers, (2) validating empirically sound judgments, and (3) facilitating expertise.

The first reason to defer to executive decision-making sounds in constitutional structure. I will not belabor the subject of coequal respect other than to observe that while separation of powers justifies due care in reviewing other branches' actions, it has never meant taking a pro forma attitude to them. A baseline of engagement is essential because the political branches already have many tools at their disposal to cow judges or otherwise resist legal judgments. Additionally, the Madisonian theory that inspired much of the Constitution's original design would operate like a stool with two legs if one branch did not vigorously serve its assigned function or defend its prerogatives.

The second justification for judicial deference is that deference helps validate the executive's empirically sound judgments. But empirically sound judgments have reasons. Blind trust, without probing the executive's reasons, is only wellplaced when it is based on a serious need and when a policy is reasonably calibrated to the actual problem. Those in power should not be able to say anything to get their way.

The third justification for judicial deference is that it facilitates expertise. This rationale does not presuppose an overly technocratic form of governance; it merely recognizes that some actors within our political system have skills and resources that are not widely available and that one reason to trust executivebranch officials is their consultation with experts who are steeped in knowledge and experience.

Given these reasons to afford a favorable standard of review to the political branches, it is sensible to build responsibility and consequence back into judicial review. Deference should disappear if a challenger makes a showing that government officials have either undermined the second reason by exhibiting an 
utter disregard for the truth, or undermined the third reason by intentionally bypassing relevant expertise.

In theory, judges are already supposed to strip official actors of deference if they act with an unconstitutional motive. The proposal here merely recognizes a broader set of democratic failings and gives reasons to suspend situationally the expectation of regular order.

Had this proposal been implemented in the travel-ban litigation, the first version of the ban would have immediately triggered greater skepticism of the government's asserted national security rationale. A small group of aides drafted that executive order and bypassed many protocols that would have included consultation with the State Department and Homeland Security - agencies that have the most reliable information about travelers, diplomatic relations, and terrorist threats. ${ }^{46}$ The order was also not approved through the National Security Council's regular process. ${ }^{47}$ Such procedural irregularity would have been enough to deny deference on the ground that it lacked the requisite expert involvement. Additionally, the mismatch between conclusory rationales such as stopping terrorism-related crimes by "foreign-born individuals" and bans against entire nations' populations could give rise to the inference that the rationales were pretextual - another reason to deny the most lenient form of review.

A streamlined burden-shifting approach could be helpful. It would initially place responsibility on a challenger to adduce facts suggesting that a President has contrived a rationale or engaged in procedural irregularities that ought to lead to the rejection of deference. Government lawyers would then have an opportunity to rebut these allegations in an effort to continue enjoying the presumption that a policy is the product of regular order.

This collapsible approach to judicial deference would undercut the ability of populist autocrats to make unusual, even radical, assertions of power under the cloak of judicial legitimacy. The mistake that conventional legal actors make is to think that such assertions of power will be one-offs rather than springboards for broader claims of power, often based on more egregious misrepresentations. The key to judicial review in a period of democratic degradation is to deny the veneer of validation to executive actions that go too far and try to redirect politics through regular channels.

The collapsible approach to deference is less strident than some other proposals out there. For instance, Mark Graber and Sandy Levinson have argued

46. See Evan Perez et al., Inside the Confusion of the Trump Executive Order and Travel Ban, CNN (Jan. 30, 2017, 11:29 AM ET), https://www.cnn.com/2017/o1/28/politics/donald-trump -travel-ban/index.html [https://perma.cc/H7FV-38FE].

47. Id. 
that any President who reveals himself to lack civic virtue should lose the presumption of regularity. ${ }^{48}$ While my proposals labor in the same spirit, theirs is broader by several orders of magnitude, completely denying judicial deference to every act by an "anti-Publian" President. This is not just strong medicine; it is a recipe for judicial superiority. Furthermore, such an overcorrection could play into the hands of a populist autocrat by giving him a weapon by which to bludgeon the courts into further submission. By contrast, my approach does not require judgment of the "character" of a democratically elected official-an already dubious inquiry. It instead trains attention on narrower concerns that can foster empirically based decision-making and stop the worst forms of dissembling.

\section{B. Emergency-Relevant Factual Review}

My second proposal goes hand in hand with the first. It offers a corrective to the general problem of insufficient attention to the factual underpinnings of emergency justifications and the President's chosen solutions. It thus addresses the problem that, even when courts do engage in rationality review rather than declaring a President's action unreviewable, they are merely undertaking a perfunctory exercise rather than anything that could discourage, or at least ferret out, manufactured crises.

The idea is to engage in some minimal review of factual assertions closely related to the invocation of emergency power. For instance, while the term "emergency" is not itself defined in the NEA, each provision spells out specific kinds of exigencies that could arise. It is important to tether a President's assertion of authority to those legislative grants without undermining the executive branch's ability to deal with the mercurial qualities of a genuine exigency.

Considering emergency-relevant evidence is critical to ensuring that a crisis is real and not contrived; that it is the kind of problem that goes beyond routine social ills; and that the serious costs associated with emergency governance will

48. Sanford Levinson \& Mark A. Graber, The Constitutional Powers of Anti-Publian Presidents: Constitutional Interpretation in a Broken Constitutional Order, 21 CHAPMAN L. REV. 133 (2018). Levinson and Graber call for "judicial improvisation" to deal with an individual who is so "manifestly unfit" to hold the office of President. Id. at 137, 154. "No one should assume Trump is engaged in rational decision making in the public interest when he makes decisions that seem better explained by his family's financial interests or his desire to avoid criminal prosecution," they write. Id. at 165. Likewise, because he campaigned on promises to violate the Constitution and "has demonstrated a fondness for white supremacists," he should broadly lose the presumption of regularity for anything his Administration does "on racial issues." Id. at 166. 
not be lightly thrust upon U.S. citizens unless there truly is an unforeseen crisis of nationwide scope.

If such minimal factual review to detect lies seems far-fetched, here is a reminder of what is possible and why it matters. Last term, the Supreme Court actually caught the Administration in a flat-out lie. It was a big lie. And for the first time, the Justices were unafraid to demand that responsible officials would face some consequences. In the surprising Census case, a 5-4 majority of the Justices, ${ }^{49}$ led by Chief Justice Roberts, found that the Administration's given reason for adding a citizenship question to the 2020 census was a pretext. The Court in Department of Commerce v. New York found that "the evidence tells a story that does not match the explanation the Secretary gave for his decision." ${ }^{50}$ The Justices did not exactly say what the real reason was (it could have been anti-Hispanic bias or a desire to entrench partisan power), but the plaintiffs had alleged that officials added the question to depress the number of responses from undocumented migrants and Hispanic citizens generally. ${ }^{51}$ The Justices did not make that particular finding, but the majority did write that the reason officials presented in court - that they needed citizenship information to enforce the Voting Rights Act - was a fib. ${ }^{22}$ It was a lie told by Commerce Secretary Wilbur Ross and repeated by lawyers to federal judges - judges who saw through the cascade of lies and were willing to call the government on it.

Because of that lie, the government could not proceed with its planned course of action. As Chief Justice Roberts explained, "The reasoned explanation requirement ... is meant to ensure that agencies offer genuine justifications for important decisions, reasons that can be scrutinized by courts and the interested public. Accepting contrived reasons would defeat the purpose of the enterprise." ${ }^{33}$ Then, tethering the significance of falsity in reason-giving to the constitutional duty of the courts, Chief Justice Roberts added: "If judicial review is to be more than an empty ritual, it must demand something better than the [contrived] explanation offered." ${ }^{54}$

Now, the government's lie was not in the national security domain, nor had the President claimed emergency power. ${ }^{55}$ But the mendacity had national

\footnotetext{
49. Dep't of Commerce v. New York, No. 18-966 (June 27, 2019).

5o. Id., slip op. at 27 .

51. Id., slip op. at 9.

52. Id., slip op. at 27 .

53. Id., slip op. at 28 .

54. Id.

55. Though the President briefly did consider claiming an emergency to add the citizenship question after losing in the Supreme Court, he never followed through on that idea. Michael Wines
} 
significance nonetheless, for political representation and federal funding would have been allocated based on the lie. Those consequences would have lasted at least ten years, until the next constitutionally mandated census. What happened in the dispute is a welcome development. To avoid the case being a one-off, we must find ways to build on its insistence upon responsible lawyering and empirical fact-finding by judges when democracy is at stake. The good news is that there is nothing special about the Court's explanation that restricts it to the subject of the Census dispute or the law at issue (the Administrative Procedure Act). Instead, its emphasis on reason-giving, truth, and reliability are general concepts that underlie all aspects of judicial review and all forms of democratic accountability. We need to take these rule-of-law concerns and apply them more broadly as we reconsider judicial tools that might no longer serve a democracy in decline.

The risk of judicial overreach can be mitigated by demanding that emergency-related fact-finding be closely tethered to statutory interpretation and congressional intentions. To the extent that statutes appear to create substantive conditions and narrow the scope of legitimate scenarios, a fact-relevant inquiry is justified whenever those conditions are invoked. If no such conditions can be gleaned from a statute, a President can hardly be punished for interpreting that law broadly. This approach will create stronger incentives on the part of Congress to specify the conditions of permissible emergencies.

Moreover, judges are competent to evaluate claims about the nature or scope of emergencies. Courts have certainly probed the nature and degree of extraordinary needs before. In other areas - notably the Fourth Amendment's "special needs" and "exigency" exceptions to the warrant rule - courts routinely demand that the government establish a need that goes above and beyond the needs of ordinary policing. They have even occasionally declared a crisis to be "beyond the normal need for law enforcement." 56

Now, let us apply this second proposal of factual review to President Trump's proclamation asserting an emergency under the NEA to reallocate military funds to finance a border wall. The proclamation states in relevant part:

The current situation at the southern border presents a border security and humanitarian crisis that threatens core national security interests and constitutes a national emergency. The southern border is a major entry point for criminals, gang members, and illicit narcotics. The problem of large-scale unlawful migration through the southern border is longstanding, and despite the executive branch's exercise of existing statutory

et al., Justice Dept. Reverses Course on Citizenship Question on Census, Citing Trump's Orders, N.Y. TimEs (July 3, 2019), https://www.nytimes.com/2019/o7/o3/us/politics/census-citizenship -question.html [https://perma.cc/AJ7E-GQUS].

56. See, e.g., Ferguson v. City of Charleston, 532 U.S. 67, 74 (2001). 
authorities, the situation has worsened in certain respects in recent years. In particular, recent years have seen sharp increases in the number of family units entering and seeking entry to the United States and an inability to provide detention space for many of these aliens while their removal proceedings are pending. If not detained, such aliens are often released into the country and are often difficult to remove from the United States because they fail to appear for hearings, do not comply with orders of removal, or are otherwise difficult to locate. ${ }^{57}$

The proclamation's factual assertions are conclusory, and there is no effort to connect the hodgepodge of possible public-policy concerns with the proposed solution of a physical border wall.

Statutes, however, explicitly limit the reasons for which a President can take money from one pot and use it for a different purpose. One of the provisions cited by the Administration-10 U.S.C. $\$ 2808$ (a) - states that funds may be moved on an emergency basis for "military construction" only when "necessary to support such use of the armed forces." 58

In particular, Congress has carefully delineated which reasons are legitimate for shifting funds relied upon by the armed forces. The Administration must make a showing that the "military construction" project envisioned will "support" the work of the armed forces rather than hurt it, and doing so is "necessary" to some serious military problem..$^{59}$ Border enforcement is generally a different agency's job. It is therefore unclear, without more details from the Administration, how a border wall will help the military deal with an existing crisis.

Moreover, some probing of the asserted emergency must take place because it is a precondition to the exercise of the power to reallocate funds. Finally, emergency-relevant probing of the facts is warranted given the enormous background constitutional principles at stake: namely, the looming concern about a President trying to make an end-run around Congress's power over the purse by faking an emergency. Engaging in minimal inquiry into the facts is less intrusive than jumping to address such an enormously fraught constitutional question and may render doing so unnecessary.

57. Proclamation No. 9844, 84 Fed. Reg. 4949 (Feb. 15, 2019).

58. 10 U.S.C. $\$ 2808(a)$ (2018). A separate provision relied on by the Administration does not require that an emergency be declared, but says that those funds can be used only for the "construction of roads and fences . . to block drug smuggling corridors across international boundaries of the United States." To the extent the Administration relies on this provision, it would have to show President Trump's proposed wall falls within the statute's definition of a "fence." Id. $\$ 284(\mathrm{~b})(7)$.

59. Id. $\$ 2808(\mathrm{a})$. 
The inquiry into the border wall illustrates one way of scrutinizing the nature of an asserted emergency and ensuring that exceptions do not swallow ordinary processes. In this example, the Administration would have to show empirically that the problems of drug smuggling and human trafficking go above and beyond normal law enforcement concerns, and, moreover, that a physical wall would actually have some effect on such crimes. Otherwise, judges would be indulging speculation and quite possibly, approving a fabricated crisis.

\section{CONCLUSION}

I will close by bringing us back to the famous Carolene Products case, ${ }^{60}$ which inspired so many modern rules of deference and theories of judicial review. If we want to remain faithful to the New Deal generation's project of reconciling democracy with judicial review, that case cannot be reduced to Footnote 4's discussion of "the presumption of constitutionality" and laws that might affect "discrete and insular minorities." Elsewhere in the opinion, Chief Justice Harlan Fiske Stone observed that deference depends upon the assumption of "knowledge and experience." ${ }^{61} \mathrm{He}$ also stressed the empirical soundness of the legislative judgments in question, saying that the law being challenged was enacted only after an "extensive investigation" and "committee hearings, in the course of which eminent scientists and health experts testified." ${ }^{2}$

We would do well to remember these original reasons that judges gave for respecting the judgments of other officials. They imply that respect is a two-way street. A political decision that is based on falsity or otherwise fails to show respect for rule-of-law values cannot receive blind confirmation, especially when someone reaches for emergency power. Allowing a fabricated crisis to stand will lead to judicial subservience and, eventually, a democracy in shambles. The answer for judges is to deny legal imprimatur to deeply troubling claims of authority and brush back government officials who play fast and loose with the facts.

Clifford Scott Green Visiting Professor of Constitutional Law, Temple University, Beasley School of Law (Fall 2019); Professor of Law, American University,

6o. United States v. Carolene Prods. Co., 304 U.S. 144 (1938). There, the Supreme Court famously upheld a law that banned "filled milk" against a constitutional challenge, proclaiming that "the existence of facts supporting the legislative judgment is to be presumed . . . unless in the light of the facts made known or generally assumed it is of such a character as to preclude the assumption that it rests upon some rational basis within the knowledge and experience of the legislators." Id. at 152.

61. Id. at 152 .

62. Id. at 148 . 
MANUFACTURED EMERGENCIES

Washington College of Law. Many thanks to Wajdi Mallat and the editors of the Yale Law Journal for their editorial assistance. 